\title{
Review
}

\section{Potential uses of milk epithelial cells: a review}

\author{
Marion BouTinAUD*, Hélène JAMMES
}

Biologie Cellulaire et Moléculaire, INRA, 78352 Jouy-en-Josas Cedex, France

\begin{abstract}
Secretions collected from the mammary gland of different species contain heterogeneous populations of cells including lymphocytes, neutrophils, macrophages and epithelial cells in different species. Several factors influence the somatic cell count in milk and the distribution of cell types, such as species, infection status, physiological status and management practices. The epithelial cells are shed into milk during the lactation process. Most of them are viable and exhibit the characteristics of fully differentiated alveolar cells. Primary cultures of epithelial cells from colostrum and milk of humans, baboons, cows and goats together with established cell lines from human and goat milk, provide a good model for the study of lactogenesis, immunity transmission, cancer research and infection by viruses. The RNA extracted from milk cells have been shown to be representative of gene expression in the mammary gland and thus provide a source of material for molecular studies of gene expression and environmental interactions.
\end{abstract}

\section{milk / somatic cell count / epithelial cells}

Résumé - Utilisations potentielles des cellules épithéliales du lait. Les sécrétions de la glande mammaire de différentes espèces, contiennent une population hétérogène de cellules incluant des cellules du système immunitaire et des cellules épithéliales. Divers facteurs influencent le nombre de cellules somatiques dans le lait et la distribution de chaque type cellulaire, en particulier l'espèce, le stade physiologique, l'état sanitaire et les conduites d'élevage. Les cellules épithéliales se détachent de l'épithélium mammaire au cours du processus de sécrétion du lait. Cependant, une grande majorité d'entre elles sont viables et présentent des caractéristiques de cellules alvéolaires totalement différenciées. En culture primaire ou en lignées cellulaires, elles constituent un modèle d'étude de l'action hormonale, de marqueurs de la cancérogenèse, de la transmission de l'immunité et d'infections virales. Les ARN totaux extraits des cellules du lait constituent une source de matériel représentatif de l'expression des gènes dans la glande mammaire et devraient permettre des études globales d'expression des gènes en interaction avec l'environnement de l'animal.

\section{lait / numération cellulaire / cellule épithéliale}

\footnotetext{
* Correspondence and reprints

E-mail: boutinau@jouy.inra.fr
} 


\section{INTRODUCTION}

Secretions collected from the mammary gland (pregnant secretions, colostrum and milk) contain heterogeneous populations of cells in different species including the human [22], caprine [58], bovine [8], porcine [33] and ovine species [35]. Milk somatic cells were first described by Donné et al. in 1838 (cited by Turner, [63]). There has thus been considerable speculation concerning the origin and function of these cells. We report here on the most important results concerning classifications based on morphological and functional characteristics. Because the predominant cell type includes immunity system cells, such as lymphocytes, neutrophils and macrophages, which are thus involved in protecting the mammary gland from infection, the somatic cell number is used as an indicator of mastitis, principally in cattle. Epithelial cells are also present in milk, being shed into it during the lactation process. Numerous reports have indicated the possibility of selecting milk epithelial cells with the characteristics of viable and differentiated alveolar epithelial cells. The purpose of this review is to report on studies and some original results obtained in our laboratory, in order to highlight the potential uses of the epithelial cells from milk.

\section{CELL TYPE DISTRIBUTION IN MILK}

The somatic cell count (SCC) varies as a function of species. On average, the SCC in an animal free of intramammary infection ranges from 0.009 in humans to $5 \times$ $10^{6}$ cells. $\mathrm{mL}^{-1}$ in caprines (Tab. I). The proportion of each cell type also varies in different species. In most species, the predominant cell type is leukocytes, including lymphocytes, polymorphonuclear neutrophils (PMN) and macrophages (Tab. I). The continuous migration of leukocytes into mammary tissue provides the first immunological line of defence against bacterial invasion $[7,22,57]$. In cows and ewes, macrophages represent a predominant cell type (35-79\%) acting as sentinels against the invasion of mastitis caused by pathogens. Once the invaders have been detected, the macrophages release chemical messengers, or chemoattractants, which trigger the migration of PMN towards the infection. PMN, which represent $5-25 \%$ of total cells, phagocytose and destroy any invading pathogens. The presence of lymphocytes in mammary secretions has also been reported; they contribute to the immune defences of new-borns in human and porcine species [4, 27, 68]. In goats, PMN constitute the major cell component among leukocytes.

Table I. Comparison of total somatic cells and cell type distribution in milk from different species (from $[16,33,44])$.

\begin{tabular}{|c|c|c|c|c|c|c|}
\hline \multirow[b]{2}{*}{ Species } & \multicolumn{6}{|c|}{ Cell types } \\
\hline & $\begin{array}{c}\mathrm{SCC} \\
10^{6} \mathrm{cell} / \mathrm{sm}\end{array}$ & $\begin{array}{l}\text { Cytoplasmic } \\
\text { particles }\end{array}$ & $\begin{array}{l}\text { Epithelial } \\
\text { cells }\end{array}$ & $\begin{array}{l}\text { Neutrophils } \\
\text { PMN }\end{array}$ & Lymphocytes & Macrophages \\
\hline Human & 0.009 & 90 & $50-90 *$ & 6 & $5-9$ & 8 \\
\hline Bovine & 0.075 & Not observed & Very low levels & $5-20$ & $20-30$ & 61 \\
\hline Ovine & 0.110 & Not observed & Very low levels & 22 & $10-25$ & 70 \\
\hline Caprine & 1.1 & 128 & $10-20$ & $45-75$ & $3-10$ & $10-35$ \\
\hline Porcine & 1 & - & $60-90$ & $5-10$ & $15-25$ & $5-10$ \\
\hline
\end{tabular}

* Human epithelial cells: foam cells and epithelial cells. 
In contrast, epithelial cells are the principal cell component in human and swine mammary secretions [7, 33, 57]. Mammary epithelial cells are exfoliated and shed into milk during lactation. Moreover, differences in milk secretion, apocrine in the goat [70] versus merocrine in the cow [69], result in an increase in the number of exfoliated epithelial cells and cell-like fragments in species such as caprines and humans [53]. These cytoplasmic particles, which have been described in human and goat milk, are rarely observed in sheep milk and are absent from cow milk (Tab. I, [16]). They are generally anucleated and contain proteins, lipids and casein micelles, and their presence is of no pathological significance. Some of these particles have been shown to contain nuclear fragments. In addition, highly vacuolated cells (foam cells) were first observed many years ago (Donné, 1838, cited by [63]) in colostrum and milk from involuting mammary glands. The origin and function of foam cells are the subject of considerable discussion. Some authors have contended that they are desquamated epithelial cells [22] while others have suggested that they may be macrophages from the blood [28, 34]. Epithelial cells contribute to the transfer of immunoglobulins (IgA) from the maternal compartment to neonates through their binding to poly-Ig receptors expressed at the basolateral surface of the epithelial cells. Intracellular enzymatic cleavage of the poly-Ig receptor gives rise to secretory $\operatorname{IgA}$ and a free secretory component (SC) in mammary secretions. Thus, milk epithelial cells may also interact with the development of local immunity in neonates of different species (swine [33]; rabbit [49]; ewes [48]).

\section{FACTORS GOVERNING VARIATIONS OF SOMATIC CELL COUNT (SCC)}

\subsection{Physiological variations}

In ruminants, changes to cell number (SCC) are well characterised and the data we describe herewith mainly concern studies in these species. The proportions of cell types vary depending on the species, and differ in colostrum and milk. In cattle, macrophages represent $10-20 \%$ of colostrum cells and predominate in milk during mid and late lactation (70-80\%), whereas PMN levels are inversely higher in colostrum (50-80\%) and lower in milk (1\%) [36]. In swine, epithelial cells represent $20-40 \%$ of all colostrum cells and $60-90 \%$ of milk cells. A drastic fall in epithelial cell number occurs during involution of the mammary gland [33].

The SCC is influenced by the stage of lactation and parity $[17,45,50]$. The SCC rises as the lactation stages progress (Fig. 1a), showing a trend which is the inverse of milk yield (Fig. 1b). This increase in the milk cell count is first due to a concentration of cells as a result of falling milk yield. Moreover as lactation progresses, it has been observed in goat milk that PMN number rises in parallel with a decrease in lymphocyte and macrophage levels without there being any correlation with an infectious state $[17,40]$. At the later stages of lactation, PMN may participate in involution of the mammary gland. It is also generally considered that the cell count increases with parity. On average, throughout lactation, a significant difference in the cell count is observed between primiparous and multiparous cows [11, 54] and sheep [23]. In goats, the effect of parity on SCC is controversial. Rota et al. [50] demonstrated an increase in SCC between the first and fourth lactations of Verata goats whereas a similar SCC for each lactation number was found by Dulin et al. [17] and Zeng et al. [71] but with specific increases in the levels of cytoplasmic particles.

In addition to the changes to SCC during lactation, weekly, individual cell count fluctuations have been described in the goat [45] as well as between two consecutive days in the cow [55] and goat [39] (Fig. 2; [6]). The significance of such short-term 

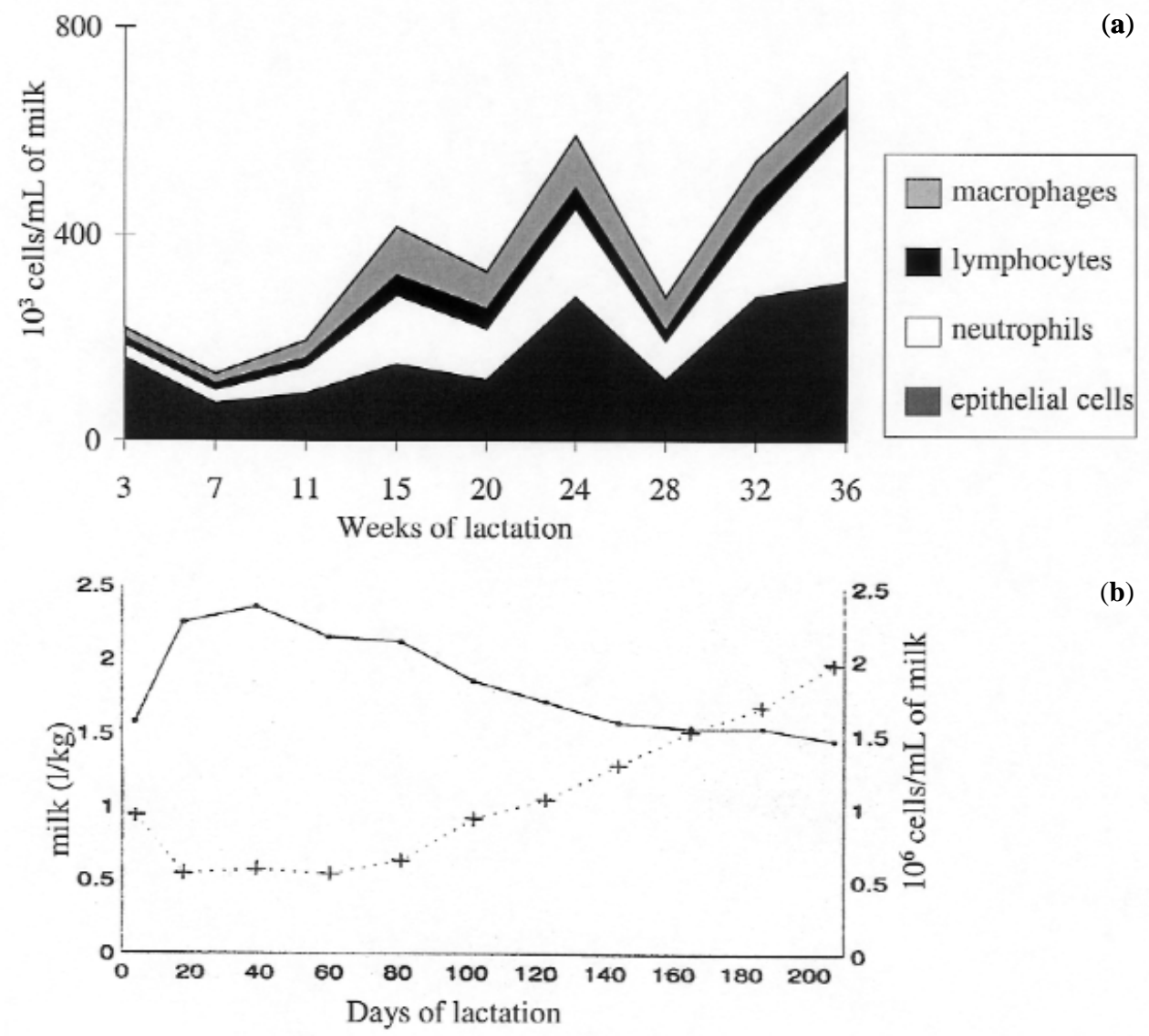

(b)

Figure 1. (a) Evolution of the somatic cell count and cell type distribution in goat milk. Total somatic cell counts were determined on milk samples at different stages of lactation by direct microscopic SCC. Samples were obtained from the glands of goats free of intramammary infection. Morphological characteristics were used to differentiate cell types (from [17]). (b) Average lactation curves of milk production and SCC in goats. Daily milk production was measured and SCC was counted directly by microscopy after DNA-specific rapid staining (from [50]).

SCC fluctuations is still unclear. Diurnal variations have also been observed. In cows, frequent foremilk sampling has indicated that cell numbers are the lowest just before milking, rise sharply during stripping, remain high for the next 4 hours and then gradually decline to a minimum towards the end of the intermilking period [55]. Similarly, in ewes, hourly variations in milk SCC have been reported during the period between milkings. SCC rises by $70 \%$ during the first hours post-milking and then gradually declines until the next milking [66]. These results emphasise the need for care in selecting the optimum time for sampling. Variations in the time of sampling may introduce real uncertainties as to the interpretation of cell count data.

The somatic cell count varies in different breeds. In a French study, milk from low-producing cow breeds (Abondance, French Simmental, Montbeliard, Tarentaise) contained fewer somatic cells than in higheryielding breeds (Prim'Holstein, Red-Pied 
Figure 2. Temporal pattern of SCC in goat milk. Daily milk samples were collected for 4 weeks from one representative goat at mid-lactation (11 weeks), during the morning milking $(300 \mathrm{~mL})$. After the isolation of somatic cells from milk by centrifugation, direct light microscopic counts were performed and somatic cells were counted in duplicate preparations. Cells with diameters greater than $10 \mu \mathrm{m}$ and with high cytoplasmic granularity were considered as epithelial cells (from [6]).

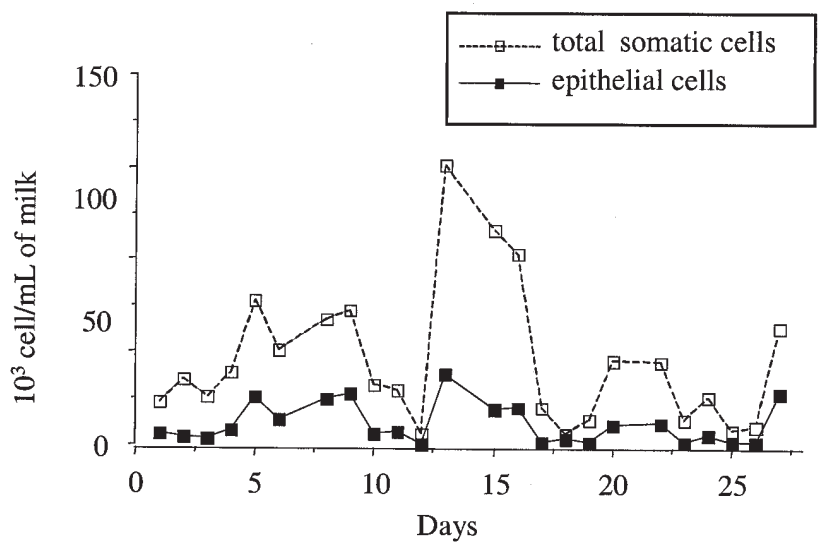

Lowland) [11, 52]. However, the SCC differences may be more linked to breed differences than to milk yield. In the goat, there is no significant difference in cell count between the Alpin and Nubian breeds [71]. It has been suggested that individual variations may also play a role in the somatic cell count.

\subsection{Management practices}

Other factors related to farm management practices can influence the somatic cell count. Milking frequency affects both SCC and milk yield. In cows, a reduction in milking frequency from twice to once a day elevates the SCC [56] whereas an increase to 4 milkings a day reduces it [65]. This phenomenon may partly be explained by the milk concentration. However, specific variations in PMN levels are observed. Milking removes dead PMN and stimulates the migration of fresh PMN into the mammary gland. Paape et al. [44] concluded that this could partially explain the reduced incidence of clinical mastitis in cows milked four times a day. Moreover, milking makes it possible to evacuate pathogens. Milking methods have been thought to influence SCC. However, no differences in levels have been observed between milk from goats [71] and ewes [24] milked using a machine or by hand. The hygiene of animal housing can affect SCC [67]. An original study reported on the effects of physical exercise on milk composition [12], and found that SCC was higher in cows that walked $9.6 \mathrm{~km} \cdot \mathrm{d}^{-1} \mathrm{com}-$ pared to those which remained indoors. In this case, the level of cells when there was a decreasing milk yield provided only a small part of the explanation for a rise in SCC. Non infectious inflammation induced by walking is suspected to have contributed to this change.

\subsection{Infection status}

The entry of pathogenic micro-organisms into the mammary gland results in inflammation of the tissue leading to an elevated SCC [25]. In the cow, cases of mastitis are also preceded by a higher SCC, which is generally considered as an indicator of infection. The SCC is a current criterion employed to estimate milk quality, and milk prices takes the SCC values into account. In goats as for cows, the SCC is likely to be considered for the milk price in the light of a recent French Ministry of Agriculture order concerning this parameter as a criterion (decret $n^{\circ}$ 2000-1347; JO December 26, 2000). However, the milk of goats free of intra-mammary 
infection shows somatic cell counts ranging from 0.05 to $5 \times 10^{6}$ cells $\cdot \mathrm{mL}^{-1}$, which is higher than the counts seen in uninfected cows. As seen above, higher levels of PMN are present in the milk of uninfected goats than in milk from uninfected cows $[15,16$, 18]. Interestingly, the incidence of clinical mastitis in dairy goats is only 1 case/100 goats/ year. The elevated neutrophil count in goat milk protects the animals against intramammary infection by the causal pathogen for mastitis. In the cow, it has also been reported that in the absence of intramammary infections, a higher SCC may increase resistance against mastitis [64]. Nevertheless, in the context of bovine selection strategies aimed at reducing the incidence of mastitis, investigations have been performed to evaluate the genetic relationships between veterinary-treated mastitis, SCC and milk production. Heritability of mastitis is low (0.024) while the heritability of SCC is moderate $(0.17)[1,2,5]$. However, the genetic correlation between the two traits is strong (0.72), suggesting a similar genetic determinism part [51]. Milk production exhibits a slightly unfavourable genetic correlation with mastitis and SCC [19, 29]. In view of these results, it has been proposed that genetic gains in terms of milk quality and resistance to mastitis may be achieved by removing animals predisposed to high SCC values. A study of SCC in sheep emphasised its use as an udder health variable following the initiation of sheep breeding programs [23].

A number of other factors that have an impact on SCC are not discussed in this review, such as nutritional and hormonal status, seasonal variations and different types of stress [25]. Feed or water deprivation results in a dramatic decrease in milk production and a proportional rise in SCC [25, 46]. Somatic cells are generally at their lowest level during the winter and rise in the summer, this change corresponding to a higher rate of coliform invasions [14] without any relationship with the increase in temperature.

In conclusion, SCC variations can mainly be explained by infection status and by variations in milk volume. During events such as infection, stress, walking or involution, the inflammatory response of the mammary gland induces a targeted migration of PMN, which represent the most variable cell component. The regulation of milk epithelial cell number is more closely dependent on the structure of the mammary epithelium, lactation stage and milking methods.

Table II. Distribution of cell types in human breast fluids (from [22]).

\begin{tabular}{|c|c|c|c|c|c|}
\hline & \multicolumn{5}{|c|}{ Cell types (\%) } \\
\hline & Cell number $\left(\times 10^{3}\right)$ & $\%$ of viability & Foam cells & Epithelial cells & Leukocytes \\
\hline $\begin{array}{l}\text { Colostrum } \\
\text { (1-2 days) }\end{array}$ & $360-480$ & $73-78$ & $72-88$ & $2-9$ & $9-20$ \\
\hline $\begin{array}{l}\text { Early lactation } \\
\text { (3-7 days) }\end{array}$ & $60-180$ & $92-95$ & $92-95$ & $2-5$ & $1-3$ \\
\hline $\begin{array}{l}\text { Mid-lactation } \\
\text { (1-2 months) }\end{array}$ & $2-10$ & $92-98$ & $92-98$ & $0-20$ & $5-8$ \\
\hline $\begin{array}{l}\text { Postweaning } \\
\text { (1-10 days) }\end{array}$ & $5-20$ & $93-97$ & $63-97$ & $2-35$ & $0-3$ \\
\hline
\end{tabular}




\section{MILK EPITHELIAL CELLS}

\subsection{Characterisation of milk epithelial cell population}

Compared with leukocytes, epithelial cells in milk are less characterised. The presence of epithelial cells has been related to milk secretion processes such as apocrine versus merocrine secretion, and their significance remains unclear. Levels of epithelial cells vary with the stage of lactation. In humans [22] and swine [33], milk contains more epithelial cells than colostrum (Tab. II).

We were recently able to characterise goat milk epithelial cells using flow cytometry. After immunostaining with an antibody directed against cytokeratin $8-18$, used as a specific marker of epithelial cells, $26 \%$ of the total cells were found to be of the epithelial type. They exhibited a broad range of sizes and cytoplasmic densities whereas the leukocyte population stained with an antibody directed against CD45, a leukocyte common antigen, was homogeneous in terms of size and density characteristics [6]. Further flow cytometric analysis showed that milk cells were stained with an anti$\alpha_{\mathrm{s} 1}$-casein antibody in the same proportion as with anti-cytokeratin antibody (Fig. 3). The percentage of cells stained with the two antibodies were strongly and significantly correlated $(R=0.98 ; P<0.03$; Tab. III $)$, but tended to be negatively correlated with the percentage of cells stained with the antiCD45 antibody. The differential antigen pattern between epithelial cells and leukocytes makes it possible to separate these cells by antibody staining and flow cytometry or using antibody-labelled beads.

It has been suggested that the presence of epithelial cells in milk provides a means of evacuating dead cells which have reached the end of their secretory life. However, although the viability of milk epithelial cells based on trypan blue exclusion is high in humans (more than 90\%), it only reaches about $40 \%$ in the goat $[6,22,62]$. During one study, we evaluated the presence of
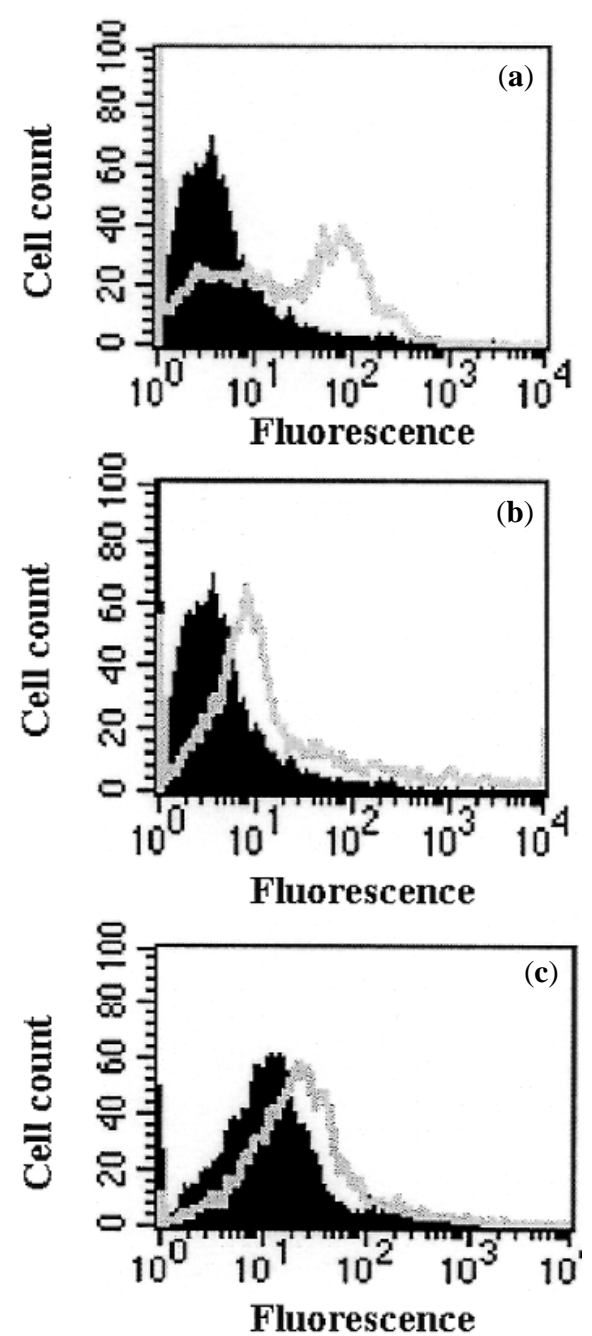

Figure 3. Flow cytometry analysis of milk somatic cells from one representative goat. Just after isolation from fresh milk, the cells were incubated in the absence (negative control) or presence of a specific primary antibody and then incubated in the presence of a second FITC conjugated antibody. The specific primary antibody was directed against CD45 in panel a, against $\alpha_{\mathrm{s} 1}$-casein in panel $b$ and against cytokeratin 8-18 in panel c. Panels a, b and c illustrate the distribution of cell populations in relation to fluorescent staining for the negative control (in black) and each staining with a specific primary antibody (grey line). The populations of CD 45-labelled lymphocytes and $\alpha_{\mathrm{s} 1}$-casein/ cytokeratin-labelled epithelial cells were counted and expressed as a percentage of the total cell count (see Tab. III). 
Table III. Distribution of milk cell types from four goats after staining with specific antibodies and analysis by flow cytometry (expressed as a percentage of the total cell count) and correlation analysis of fluorescent staining with antibodies directed against CD45, casein and cytokeratin 8-18.

\begin{tabular}{lccc}
\hline & \multicolumn{3}{c}{ Primary antibody } \\
\cline { 2 - 4 } & Anti-CD45 & Anti-cytokeratin & Anti- $\alpha_{\mathrm{s} 1}$-casein \\
\hline Goat 1 & 65.5 & 21.8 & 27.1 \\
Goat 2 & 43.0 & 24.4 & 29.3 \\
Goat 3 & 68.3 & 12.3 & 18.8 \\
Goat 4 & 36.5 & 45.6 & 38.5 \\
\hline & $\mathrm{CD} 45 / \alpha_{\mathrm{s} 1}$-casein & CD45/cytokeratin & Cytokeratin $/ \alpha_{\mathrm{s} 1}$-casein \\
\hline Correlation $R$ & -0.85 & -0.88 & 0.98 \\
$P$ & 0.15 & 0.12 & 0.03 \\
\hline
\end{tabular}

apoptotic cells in milk somatic cell preparations using an in situ cell death detection kit (TUNEL assay). Four milk cell preparations from fresh goat milk were stained with TUNEL and analysed by flow cytometry to determine the apoptotic index. Stained cells remained undetectable in two preparations, but in the other 2 samples, only $10 \%$ of the total milk cells were shown to be apoptotic. Stained cells also exhibited the size and cytoplasmic density characteristics of milk epithelial cells (Fig. 4). This result showed that a small proportion $(<30 \%)$ of milk epithelial cells exhibited an apoptotic DNA pattern. Probably because the cytoplasmic particles without a nucleus were not stained by TUNEL, the apoptotic index value was lower than the dead cell level observed with trypan blue exclusion. Certain other arguments have demonstrated the viability of milk epithelial cells. In particular, as described below, several studies have demonstrated the growth properties and hormone sensitivity of milk epithelial cells.

\subsection{In vitro milk epithelial cell studies}

\subsubsection{Experimental conditions}

Primary cultures of exfoliated epithelial cells from colostrum and milk were first established in human milk [7], then in the baboon [47], goat [58], cow [8] and swine [32]. Mammary secretions are a convenient source of epithelial cells for the study of growth, differentiation and cell line establishment [7, 9, 21, 43, 60]. In human milk, the epithelial cell population represents the predominant cell type and is not homogeneous. Following prolonged in vitro maintenance, two cell types can be identified. The first, most common cell constituent of milk is adherent, non-dividing, large cells, which are called "foam cells". These cells are characterised by their large size, the polarity of their cytoplasmic organelles, variations in the number and size of lipid vacuoles and condensed chromatin. The second cell type consists in a small number of compact cell clusters, forming epithelial cell colonies. These cells exhibit the structural characteristics of cuboid cells lining the ducts and alveoli mammary tissue. The cells appear to be inert for the first two days of culture, after which both small and large cells are able to adhere to plastic dishes, making it possible to distinguish them from lymphocytes and granulocytes which remain in suspension. Patches of proliferating epithelial cells begin to appear in which mitotic figures are evident. Through clonal analysis of epithelial cells presenting the 
ability to divide in vitro, three different classes of colony forming cells may be observed: tightly jointed elongated cells, tightly jointed cuboidal cells and an open arrangement of non-contiguous cells. The presence of these three types of colony is probably linked to their differentiation stage
[57]. In addition, cells in culture from goat milk are positively stained with an anticytokeratin antibody [42]. Paradoxically, the diversity of response of human milk cells to a monoclonal antibody raised against a component of human milk fat globules has been observed and correlated with differential

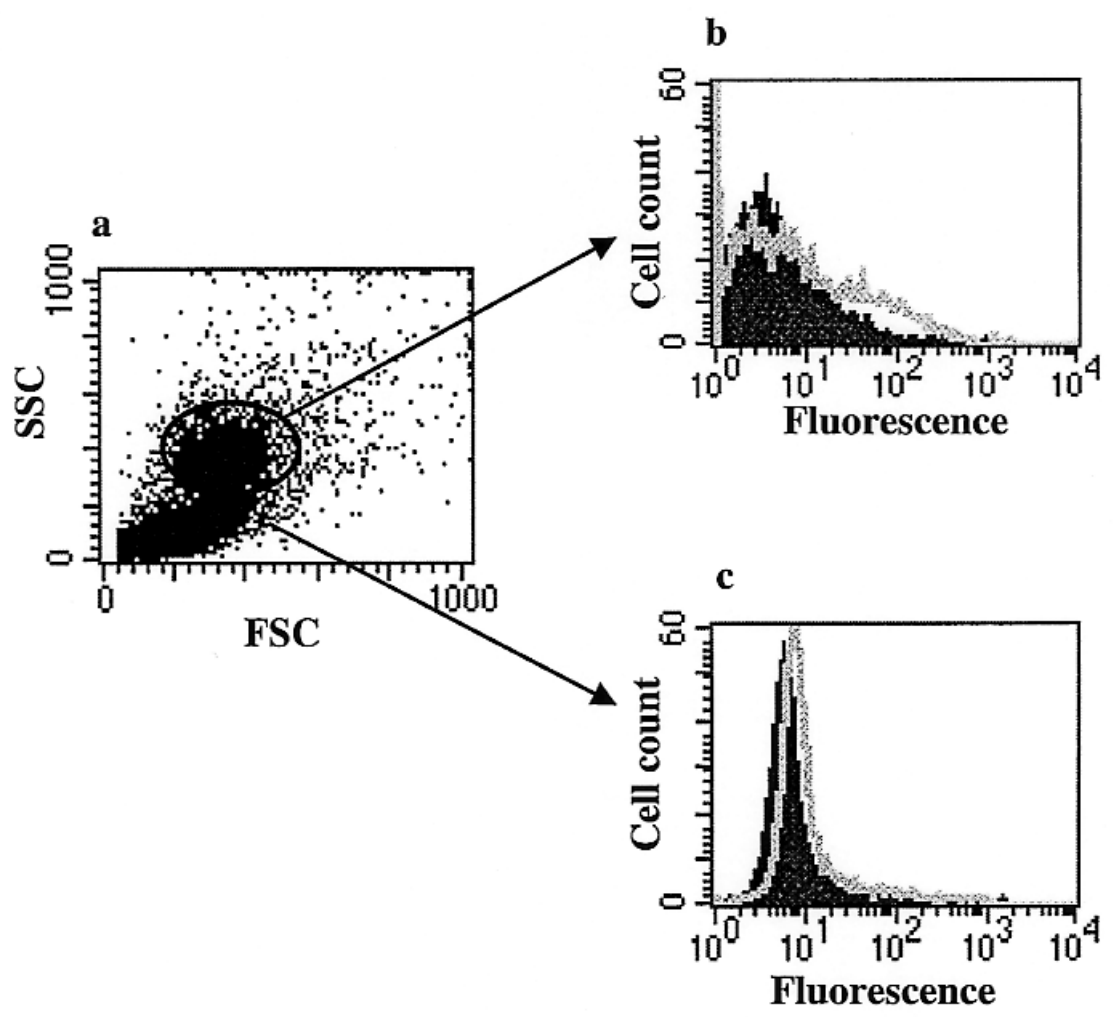

Figure 4. Characterisation of the light scattering properties of milk somatic cells stained using an in situ cell death detection kit (Roche Diagnostic GmbH, Germany). Endonucleolysis is considered as the key biochemical event of apoptosis, resulting in the cleavage of nuclear DNA into oligonucleosome-sized fragments. The in situ detection of apoptotic cells uses a terminal deoxynucleotidyl transferase dUTP nick end labelling (TUNEL) to visualise cells exhibiting DNA degradation. Fresh milk cells were incubated in the absence (sample 1, negative control, in black) or in the presence of terminal deoxynucleotidyl transferase (sample 2, grey line), which catalyses the incorporation of fluorescein-labelled nucleotides to free 3'OH DNA ends generated by endonucleolysis. Similar forward scatter height (FSC) versus side scatter height (SSC) dot blot profiles were obtained for the two samples and are shown in panel a. For each sample, the milk cell population was heterogeneous in terms of size (FSC) and cytoplasmic density (SSC). We have previously demonstrated that the epithelial cell population varied considerably in size and cytoplasmic density. Fluorescent staining of the epithelial cell population is analysed in panel b. Some staining was observed. The proportion of milk epithelial cells detected by the TUNEL assay reached $30 \%$ of the epithelial cell population. In contrast, milk leukocytes constituted a homogeneous cell population of small size and low density. The fluorescent staining of leukocytes is shown in panel c. No staining of leukocytes was observed. 
in vitro growth potential [10]. In swine mammary secretions, epithelial cells from colostrum exhibit in vitro proliferative properties suggesting an undifferentiated status. However, milk epithelial cells shown a lack of proliferation, indicating that these cells may exhibit the characteristics of fully differentiated alveolar epithelial cells [32].

\subsubsection{Establishment of cell lines}

Although the replicative life of milk epithelial cells is relatively long, reaching more than 50 passages, different mammary epithelial cell lines have been established from milk. A continuous cell line, HBL-100 was obtained from primary cultures of cells derived from an early lactation sample of human milk. HBL-100 cells exhibit several transformation characteristics, including the ability to form colonies in soft agar and achieve continuous growth [21]. Luminal epithelial cells cultured from human milk have been immortalised by introducing the gene encoding the simian virus 40 large tumour $\mathrm{T}$ antigen [3]. The cell lines express keratins, including keratins 7, 8, 18 and 19 but do not express keratin 14 or vimentin. This keratin expression profile corresponds to common luminal epithelial cells. Recently, epithelial cells were isolated from the milk of uninfected goats and three cell lines were established using the SV40 large $\mathrm{T}$ antigen. All three cell lines conserved epithelial characteristics and constitutively expressed the large $\mathrm{T}$ antigen [43].

\subsubsection{Lactogenesis studies}

Primary cultures of milk epithelial cells and milk epithelial cell lines constitute an in vitro system for the study of the proliferation and differentiation of mammary epithelial cells. This is a clear improvement on the use of biopsy procedures or animal slaughter, being non-invasive and more economical. The small numbers of epithelial cells in cow milk remains a disadvantage in terms of using milk cells as a source of bovine mammary epithelial cells [8]. The culture of milk cells also provides a mean of obtaining mammary cells free from fibroblast contamination. The use of milk cell cultures also provides an opportunity to assess the responsiveness of epithelial cells to hormone and growth factor stimulation, without the interaction of any other cells. A hydrocortisone, non-insulin effect has been demonstrated on the growth of dividing cells cultivated from early lactation human milk [61]. It has also been shown that non-dividing foam cells can act as a feeder influencing the growth and development of epithelial cells. However, the molecules involved in this phenomenon have still not been determined.

\subsubsection{Cancer research}

Since early reports concerning the culture of human milk epithelial cells, the possibility of applications in cancer research has been considered. Most human breast tumours arise from the mammary epithelial cells which line the milk duct and milksecreting cells [7]. All studies of epithelial cell cultures from human breast secretions have reported that these cells constitute a source of normal, fibroblast-free mammary epithelial cells. In women, normal tissues are mostly obtained during breast surgery and are inevitably accompanied by connective tissue. Moreover, the availability of tissue samples from lactating women is very limited. Epithelial cell cultures from milk could provide basic tools for studying the differentiation events and carcinogenesis of mammary epithelial cells. A comparison of the behaviour of cancer and normal cells in culture, might make it possible to differentiate their growth properties and drug and hormone sensitivities. We report here on three studies which constitute examples of the application of milk epithelial cells in cancer research. Normal cells from human breast secretions exhibit optimum growth in medium buffered to $\mathrm{pH} 6.8$, and are sensitive to the proliferative effect of 
epidermal growth factor, whereas the growth of malignant cells is relatively unaffected by $\mathrm{pH}$ and by hormonal stimulation [30]. Human milk epithelial cells could be used to test antigenic markers and compare cancer tissue with normal cells [59]. In this context, monoclonal antibodies directed against components of the human milk fat globule membrane (HMFG) provide a useful tool for binding with a high degree of specificity to breast sections, mammary tumours in mice and human milk epithelial cells. Breast milk cells have also been used for research on biomarkers of putative breast carcinogens, such as DNA adducts after DNA extraction [62].

\subsubsection{Immunology research}

In monogastric animals, lactogenic immunity is largely dependent upon secretory $\operatorname{Ig} \mathrm{A}$, which is considered to result from the active processing of dimeric IgA produced by epithelial cells. Secretory IgA in mammary secretions results from the cell translocation of dimeric IgA via the polyIg receptor, and their secretion into the lumen. In swine colostrum, $20 \%$ of total cells are small epithelial cells (with a diameter ranging from 9 to $15 \mu \mathrm{m}$ ), exhibiting weakly positive membrane secretory component staining. Ten per cent of epithelial cells contain intracytoplasmic IgA. During late lactation, milk epithelial cells represent $70 \%$ of total cells and are larger (15 to $40 \mu \mathrm{m})$, with a high expression of both the membrane and cytoplasmic secretory components. Most epithelial cells express intracytoplasmic IgA. This study focused on the possible involvement of milk epithelial cells in transmitting humoral lactogenic immunity to neonates [32].

The presence of particles with known oncornavirus-like properties has been reported in milk cells from apparently healthy lactating women [20]. The relationship between viruses and the epidemiological risk of breast cancer, and that between these oncornavirus-like particles and those found in human milk, need to be clarified. Recently, primary cultures of goat milk epithelial cells were used to study infection by CAEV [42]. Milk epithelial cells in culture were easily infected by the virus and produced it at high levels. The authors concluded that these findings could help to explain the high efficiency of CAEV transmission in milk.

\subsection{Ex vivo gene expression studies}

A simple procedure to isolate mRNA directly from milk cells has also been reported [38, 41]. The existence of $\alpha_{\mathrm{s} 1}$-casein polymorphism in humans, previously shown in goats and cows, was demonstrated by the reverse transcriptase polymerase chain reaction technique (RT-PCR) using RNA from human milk epithelial cells [41]. Similarly, $\beta$ casein mRNA and its gene were studied in epithelial cells isolated from human milk [38] and from bovine colostrum [26]. Despite the presence of ribonuclease in milk [13], the RNA quality is sufficient to enable the study of $\beta$ casein mRNA by Northern blot. However RNA are sensitive to storage conditions: the freezing and thawing of milk degrades mRNA. The isolation of RNA from milk cells and the RT-PCR technique have been successfully applied to the detection of lentiviral infection in milk, to mammary secretions from small ruminants [37] or the expression of the pIgA receptor gene in swine colostrum. In the latter case, milk cell RNA was used to obtain the sequence of porcine pIgA receptor cDNA [31].

We recently explored the possibility of using somatic cells isolated from goat milk as a source of mammary tissue RNA in order to evaluate the regulation of mammary gene expression [6]. The efficiency rate of RNA preparation achieved $(0.3 \mathrm{mg}$ of RNA/10 000 somatic cells) corresponded to that of classical RNA preparations in cell cultures. 
pIgA receptor

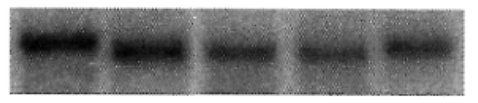

Kappa casein

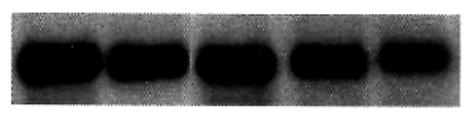

$4 \mathrm{~kb}$

$0.8 \mathrm{~kb}$

Figure 5. Analysis of kappa casein and pIgA receptor gene expression by northern blot using somatic cell RNA extracted from five goat milk samples. Northern blot was performed with a gel containing $10 \mu \mathrm{g}$ total RNA, previously extracted from fresh milk somatic cells. The membrane was successively hybridised with ${ }^{32} \mathrm{P}$ labelled- kappa casein and $\mathrm{pIgA}$ receptor cDNA probes.

Gene expression in goat milk cells has been shown to be representative of gene expression in the mammary gland. First, the relative expression of different $\alpha_{\mathrm{s} 1}$-casein variants in milk cells corresponds to the protein content in milk. A comparison of mRNA extracted from mammary tissue with that of congruently collected cells from milk analysed by northern blot showed that milk protein gene expression was conserved in both samples. Finally milk cell RNA has been used as a tool to elucidate the mechanism of $\mathrm{GH}$ action on the mammary gland. A GH stimulation of three milk protein gene expressions was found at days 3 and 4 of $\mathrm{GH}$ treatment in goats. Using the ovine cDNA pIgA receptor as a probe [48], we analysed goat milk cell RNA by northern blot. A single RNA of $4 \mathrm{~kb}$ coding the pIgA receptor was found, similar to that in the rabbit [49] and sheep [48]. We observed a relative correlation between the expression of kappa casein and pIgA receptor genes (Fig. 5). Clearly, the use of milk somatic cells permits the study of the expression of several genes in epithelial cells without the contamination by fibroblast or myoepithelial cell RNA.

\section{CONCLUSION}

Differences in milk secretions give rise to various numbers and types of cells present in milk from different species. More data are required to gain a clearer understanding of these differences. A large number of factors have been shown to affect the somatic cell count and, as a result the number of epithelial cells.

The presence of epithelial cells in milk suggests a broad spectrum of applications in different fields. Milk epithelial cells represent a good model for the study of lactogenesis, virus or immunity transmission and cancer research in both ruminants, humans and swine. These studies can be performed in vitro using fresh cells in culture or milk epithelial cell lines. Exfoliated epithelial cells may be separated from milk for RNA extraction, providing quantities that are sufficient for the molecular epidemiological study of gene expression and environmental interactions.

\section{REFERENCES}

[1] Banos G., Shook G.E., Genotype by environment interaction and genetic correlations among parities for somatic cell count and milk yield, J. Dairy Sci. 73 (1990) 2563-2573.

[2] Baro J.A., Carriedo J.A., San Primitivo F., Genetic parameters of test day measures for somatic cell count, milk yield, and protein percentage of milking ewes, J. Dairy Sci. 77 (1994) 2658-2662.

[3] Bartek J., Bartkova J., Kyprianou N., Lalani E.N., Staskova Z., Shearer M., Chang S., Taylor-Papadimitriou J., Efficient immortalization of luminal epithelial cells from human mammary gland by introduction of simian virus 40 large tumor antigen with a recombinant retrovirus, Proc. Natl. Acad. Sci. USA 88 (1991) 3520-3524

[4] Bertotto A., Gerli R., Fabietti G., Crupi S., Arcangeli C., Scalise F., Vaccaro R., Human breast milk T lymphocytes display the phenotype and functional characteristics of memory T cells, Eur. J. Immunol. 20 (1990) 1877-1880. 
[5] Boettcher P.J., Dekkers J.C., Kolstad B.W., Development of an udder health index for sire selection based on somatic cell score, udder conformation, and milking speed, J. Dairy Sci. 81 (1998) 1157-1168.

[6] Boutinaud M., Rulquin H., Keisler D.H., Djiane J., Jammes H., Use of somatic cells from goat milk for dynamic studies of gene expression in the mammary gland, J. Anim. Sci. 80 (2002) $1258-1269$.

[7] Buehring G.C., Culture of human mammary epithelial cells: keeping abreast with a new method, J. Natl. Cancer Inst. 49 (1972) 1433-1434.

[8] Buehring G.C., Culture of mammary epithelial cells from bovine milk, J. Dairy Sci. 73 (1990) 956-963.

[9] Ceriani R.L., Taylor-Papadimitriou J., Peterson J.A., Brown P., Characterization of cells cultured from early lactation milks, In Vitro 15 (1979) 356-362.

[10] Chang S.E., Taylor-Papadimitriou J., Modulation of phenotype in cultures of human milk epithelial cells and its relation to the expression of a membrane antigen, Cell Differ. 12 (1983) 143-154.

[11] Coulon J.-B., Dauver F., Garel J.P., Facteurs de variation de la numération cellulaire du lait chez des vaches laitières indemnes de mammites cliniques, INRA Prod. Anim. 9 (1996) 133-139.

[12] Coulon J.B., Pradel P., Cochard T., Poutrel B., Effect of extreme walking conditions for dairy cows on milk yield, chemical composition, and somatic cell count, J. Dairy Sci. 81 (1998) 994-1003.

[13] Dalaly B.K., Eitenmiller R.R., Friend B.A., Shahani K.M., Human milk ribonuclease, Biochim. Biophys. Acta 615 (1980) 381-391.

[14] Dohoo I.R., Meek A.H., Martin S.W., Somatic cell counts in bovine milk: relationships to production and clinical episodes of mastitis, Can. J. Comp. Med. 48 (1984) 130-135.

[15] Droke E.A., Paape M.J., Di Carlo A.L., Prevalence of high somatic cell counts in bulk tank goat milk, J. Dairy Sci. 76 (1993) 1035-1039.

[16] Dulin A.M., Paape M.J., Berkow S., Hamosh M., Hamosh P., Comparison of total somatic cells and differential cellular composition in milk from cows, sheep, goats, and humans, Fed. Proc. 42 (1983) 1331.

[17] Dulin A.M., Paape M.J., Schultze W.D., Weinland B.T., Effect of parity, stage of lactation, and intramammary infection on concentration of somatic cells and cytoplasmic particles in goat milk, J. Dairy Sci. 66 (1983) 2426-2433.

[18] Fahr R.D., Schulz J., Finn G., von Lengerken G., Walther R., Cell count and differential cell count in goat milk-variability and influencing factors, Tierarztl. Prax. Ausg. G. Grosstiere Nutztiere 27 (1999) 99-106.
[19] Fetrow J., Anderson K., Sexton S., Herd composite somatic cell counts: average linear score and weighted average somatic cell count score and milk production, J. Dairy Sci. 71 (1988) 257-260.

[20] Furmanski P., Longley C., Fouchey D., Rich R., Rich M.A., Normal human mammary cells in culture: evidence for oncornavirus-like particles, J. Natl. Cancer Inst. 52 (1974) 975-977.

[21] Gaffney E.V., A cell line (HBL-100) established from human breast milk, Cell Tissue Res. 227 (1982) 563-568

[22] Gaffney E.V., Polanowski F.P., Blackburn S.E., Lambiase J.P., Origin, concentration and structural features of human mammary gland cells cultured from breast secretions, Cell Tissue Res. 172 (1976) 269-279.

[23] Gonzalo C., Carriedo J.A., Gomez J.D., Gomez L.D., San Primitivo F., Diurnal variation in the somatic cell count of ewe milk, J. Dairy Sci. 77 (1994) 1856-1859.

[24] Gonzalo C., Gaudioso V.R., Evolution des types cellulaires du lait de brebis (race Churra) en fonction des dénombrements cellulaires totaux pendant la traite mécanique et manuelle, Ann. Zootech. 34 (1985) 257-264.

[25] Harmon R.J., Physiology of mastitis and factors affecting somatic cell counts, J. Dairy Sci. 77 (1994) 2103-2112.

[26] Imamura M., Itagaki M., Tanimoto Y., Kurosawa S., Isolation, culture and alpha ${ }_{\mathrm{s} 1}$ casein mRNA detection of colostrum derivated bovine mammary epithelial cells, 8th AAAP Animal Science Congress, 1996.

[27] Jain L., Vidyasagar D., Xanthou M., Ghai V., Shimada S., Blend M., In vivo distribution of human milk leucocytes after ingestion by newborn baboons, Arch. Dis. Child 64 (1989) 930-933.

[28] Jensen D.L., Eberhart R.J., Macrophages in bovine milk, Am. J. Vet. Res. 36 (1975) 619-624.

[29] Kehrli M.E. Jr., Shuster D.E., Factors affecting milk somatic cells and their role in health of the bovine mammary gland, J. Dairy Sci. 77 (1994) 619-627.

[30] Kirkland W.L., Yang N.S., Jorgensen T., Longley C., Furmanski P., Growth of normal and malignant human mammary epithelial cells in culture, J. Natl. Cancer Inst. 63 (1979) 29-41.

[31] Kumura B.H., Sone T., Shimazaki K., Kobayashi E., Sequence analysis of porcine polymeric immunoglobulin receptor from mammary epithelial cells present in colostrum, J. Dairy Res. 67 (2000) 631-636.

[32] Le Jan C., Secretory component and IgA expression by epithelial cells in sow mammary gland and mammary secretions, Res. Vet. Sci. 55 (1993) 265-270. 
[33] Le Jan C., Cellular components of mammary secretions and neonatal immunity: a review, Vet. Res. 27 (1996) 403-417.

[34] Lee C.S., Lascelles A.K., The histological changes in involuting mammary glands of ewes in relation to the local allergic response, Aust. J. Exp. Biol. Med. Sci. 47 (1969) 613-623.

[35] Lee C.S., Outteridge P.M., Leucocytes of sheep colostrum, milk and involution secretion, with particular reference to ultrastructure and lymphocyte sub-populations, J. Dairy Res. 48 (1981) 225-237.

[36] Lee C.S., Wooding F.B., Kemp P., Identification, properties, and differential counts of cell populations using electron microscopy of dry cows secretions, colostrum and milk from normal cows, J. Dairy Res. 47 (1980) 39-50.

[37] Leroux C., Lerondelle C., Chastang J., Mornex J.F., RT-PCR detection of lentiviruses in milk or mammary secretions of sheep or goats from infected flocks, Vet. Res. 28 (1997) 115-121.

[38] Lindquist S., Hansson L., Hernell O., Lonnerdal B., Normark J., Stromquist M., Bergstrom S., Isolation of mRNA and genomic DNA from epithelial cells in human milk and amplification by PCR, Biotechniques 17 (1994) 692-696.

[39] Linzell J.L., Peaker M., Day-to-day variations in milk composition in the goat and cow as a guide to the detection of subclinical mastitis, Br. Vet. J. 128 (1972) 284-295.

[40] Manlongat N., Yang T.J., Hinckley L.S., Bendel R.B., Krider H.M., Physiologic-chemoattractant-induced migration of polymorphonuclear leukocytes in milk, Clin. Diagn. Lab. Immunol. 5 (1998) 375-381.

[41] Martin P., Brignon G., Furet J.P., Leroux C., The gene encoding as1-casein is expressed in human mammary epithelial cells during lactation, Lait 76 (1996) 523-535.

[42] Mselli-Lakhal L., Guiguen F., Fornazero C., Du J., Favier C., Durand J., Grezel D., Balleydier S., Mornex J.F., Chebloune Y., Goat milk epithelial cells are highly permissive to CAEV infection in vitro, Virology 259 (1999) 67-73.

[43] Mselli-Lakhal L., Guiguen F., Fornazero C., Favier C., Durand J., Grezel D., Moussa A., Mornex J.F., Chebloune Y., Immortalized goat milk epithelial cell lines replicate CAEV at high level, Vet. Res. 32 (2001) 429-440.

[44] Paape M.J., Capuco A.V., Cellular defense mechanisms in the udder and lactation of goats, J. Anim. Sci. 75 (1997) 556-565.

[45] Pettersen K.E., Cell content in goat's milk, Acta Vet. Scand. 22 (1981) 226-237.

[46] Reneau J.K., Effective use of dairy herd improvement somatic cell counts in mastitis control, J. Dairy Sci. 69 (1986) 1708-1720.

[47] Rie E.J., Rie I.P., Buehring G.C., Short-term line of normal baboon mammary epithelial cells, J. Natl. Cancer Inst. 57 (1976) 609-611.
[48] Rincheval-Arnold A., Belair L., Djiane J., Developmental expression of $\mathrm{pIgR}$ gene in sheep mammary gland and hormonal regulation, J. Dairy Res. 69 (2002) 13-26.

[49] Rosato R., Jammes H., Belair L., Puissant C., Kraehenbuhl J.P., Djiane J., Polymeric-Ig receptor gene expression in rabbit mammary gland during pregnancy and lactation: evolution and hormonal regulation, Mol. Cell. Endocrinol. 110 (1995) 81-87.

[50] Rota A.M., Gonzalo C., Rodriguez P.L., Rojas A.I., Martin L., Tovar J.J., Effects of stage of lactation and parity on somatic cell counts in milk of Verata Goats and algebraic models of their lactation curves, Small Rumin. Res. 12 (1993) 211-219.

[51] Rupp R., Boichard D., Relations génétiques entre numération cellulaire, mammite clinique, production laitière et quelques caractères de morphologie, Journées Nationales GTVINRA - Cellules somatiques du lait, Nantes, 1999, pp. 153-158.

[52] Rupp R., Boichard D., Bertrand C., Bazin S., Bilan national des numérations cellulaires dans le lait des différentes races bovines laitières françaises, INRA Prod. Anim. 13 (2000) 257-267.

[53] Schalm O.W., Caroll E.J., Jain N.C., Bovine mastitis, Philadelphia, PA, 1971.

[54] Sheldrake R.F., Hoare R.J., McGregor G.D., Lactation stage, parity, and infection affecting somatic cells, electrical conductivity, and serum albumin in milk, J. Dairy Sci. 66 (1983) 542-547.

[55] Smith J.W., Schultze W.D., Variation in cell content of milk associated with time of sample collection. I. Diurnal variation, J. Dairy Sci. 50 (1967) 1083-1087.

[56] Stelwagen K., Lacy-Hulbert S.J., Effect of milking frequency on milk somatic cell count characteristics and mammary secretory cell damage in cows, Am. J. Vet. Res. 57 (1996) 902-905.

[57] Stoker M., Perryman M., Eeles R., Clonal analysis of morphological phenotype in cultured mammary epithelial cells from human milk, Proc. R. Soc. Lond. B Biol. Sci. 215 (1982) 231-240.

[58] Tateyama S., Kawano A., Yamaguchi R., Nosaka D., Kondo F., Culture conditions and cell morphology of goat milk-derived mammary epithelial cells in plate culture, Nippon Juigaku Zasshi 50 (1988) 1192-1199.

[59] Taylor-Papadimitriou J., Peterson J.A., Arklie J., Burchell J., Ceriani R.L., Bodmer W.F., Monoclonal antibodies to epithelium-specific components of the human milk fat globule membrane: production and reaction with cells in culture, Int. J. Cancer 28 (1981) 17-21.

[60] Taylor-Papadimitriou J., Shearer M., Stoker M.G., Growth requirements of human mammary epithelial cells in culture, Int. J. Cancer 20 (1977) 903-908. 
[61] Taylor-Papadimitriou J., Shearer M., Tilly R., Some properties of cells cultured from earlylactation human milk, J. Natl. Cancer Inst. 58 (1977) 1563-1571.

[62] Thompson P.A., Kadlubar F.F., Vena S.M., Hill H.L., McClure G.H., McDaniel L.P., Ambrosone C.B., Exfoliated ductal epithelial cells in human breast milk: a source of target tissue DNA for molecular epidemiologic studies of breast cancer, Cancer Epidemiol. Biomarkers Prev. 7 (1998) 37-42.

[63] Turner C.W., The Mammary gland. 1. The Anatomy of the udder of Cattle and Domestic Animals, Chapter 12, Columbia, Missouri, Lucas Brothers, 1952.

[64] Vandeputte-Van Messom G., Burvenich C., Roets E., Massart-Leen A.M., Heyneman R., Kremer W.D., Brand A., Classification of newly calved cows into moderate and severe responders to experimentally induced Escherichia coli mastitis, J. Dairy Res. 60 (1993) 19-29.

[65] Waterman D.F., Harmon R.J., Hemken R.W., Langlois B.E., Milking frequency as related to udder health and milk production, J. Dairy Sci. 66 (1983) 253-258.
[66] White F., Rattray E.A., Diurnal variation in the cell content of cows' milk, J. Comp. Pathol. 75 (1965) 253-261.

[67] Wilson D.J., Das H.H., Gonzalez R.N., Sears P.M., Association between management practices, dairy herd characteristics, and somatic cell count of bulk tank milk, J. Am. Vet. Med. Assoc. 210 (1997) 1499-1502.

[68] Wirt D.P., Adkins L.T., Palkowetz K.H., Schmalstieg F.C., Goldman A.S., Activated and memory T lymphocytes in human milk, Cytometry 13 (1992) 282-290.

[69] Wooding F.B., Morgan G., Craig H., "Sunbursts" and "christiesomes": cellular fragments in normal cow and goat milk, Cell Tissue Res. 185 (1977) 535-545.

[70] Wooding F.B., Peaker L.J., Theories of milk secretion: evidence from electron microscopic examination of milk, Nature 226 (1970) 762-764.

[71] Zeng S.S., Escobar E.N., Effect of parity and milk production on somatic cell count, standard plate count and composition of goat milk, Small Rumin. Res. 17 (1995) 269-274. 